\title{
IN VITRO GLYCATION OF AMINOTRANSFERASES: A PROCESS CLOSELY DEPENDING ON THE EMPLOYED EXPERIMENTAL CONDITIONS
}

\author{
Martin Beránek ${ }^{1}$, Jaroslav Dršata ${ }^{2,}$ Vladimír Paličcka \\ University Hospital in Hradec Králové: Institute of Clinical Biochemistry and Diagnostics ${ }^{1}$; Charles University in Prague, \\ Faculty of Pharmacy in Hradec Králové and the Research Centre LN00B125 2
}

\begin{abstract}
Summary: The aim of the present study is to investigate the influence of various experimental conditions, i.e., two different concentrations of D-fructose as a rapidly glycating substance and three incubation temperatures, on the glycation reaction of alanine aminotransferase (ALT, EC 2.6.1.2) and aspartate aminotransferase (AST, EC 2.6.1.1) expressed by decreasing catalytic activities of the enzymes during a 56 day in vitro incubation period. D-fructose in the concentration of $50 \mathrm{mmol} / 1$ did not inhibit the catalytic activity of either enzyme at $4{ }^{\circ} \mathrm{C}$, partially inhibited AST activity in samples incubated at $25{ }^{\circ} \mathrm{C}$ (to $40 \%$ of the initial activity), and completely inhibited this enzyme at $37{ }^{\circ} \mathrm{C}$ at the end of the incubation period. In the presence of the same concentration of D-fructose, ALT showed no catalytic activity after 35 days at $25^{\circ} \mathrm{C}$ or after 10 days at $37^{\circ} \mathrm{C}$. In $500 \mathrm{mmol} / 1 \mathrm{D}$-fructose, complete AST inhibition was observed after 35 days $\left(25^{\circ} \mathrm{C}\right)$ or 20 days $\left(37^{\circ} \mathrm{C}\right.$ ), and no ALT activity was found on day 20 at either $25^{\circ} \mathrm{C}$ or $37^{\circ} \mathrm{C}$. Taking into account the highest possible stability of enzymes, we suppose that a three-week observation of their residual catalytic activity in the presence of 50 $\mathrm{mmol} / \mathrm{l} \mathrm{D}$-fructose at the temperature of $25^{\circ} \mathrm{C}$ seems to be the most prospective experimental design for future glycation studies with aminotransferases under the influences of drugs.
\end{abstract}

Key words: Glycation; Enzyme; ALT; AST; Fructose; Incubation; Catalytic activity; Inhibition

\section{Introduction}

Alanine aminotransferase (ALT, EC 2.6.1.2) and aspartate aminotransferase (AST, EC 2.6.1.1), very useful enzymes in clinical laboratory diagnostics, catalyse the reversible conversion of amino acids L-alanine and L-aspartate to pyruvate and oxaloacetate, respectively. The protein part of aminotransferase molecules, consisting of two identical, non-covalently bound subunits, binds one molecule of the coenzyme pyridoxal-5'-phosphate (PLP) to a lysine residue (Lys313 in ALT and Lys258 in AST) of each subunit. About 15-20 other lysine residues are present in their molecules outside the active site whose number and position in protein chains vary according to species and intracellular location $(8,10)$.

Non-enzymatic glycation, a post-translational change of the protein part of enzymes, can modify the catalytic activity of aminotransferases. Previously published studies found that the kinetics of glycation either in vivo or in vitro depends on the type and concentration of monosaccharides in the medium, the number of amino groups in lysine residues, and the biological half-life of the protein (4). In vitro experiments demonstrate that aminotransferases can be effectively glycated with monosaccharides in the order D-glucose < D-fructose < D-ribose < D, L-glyceraldehyde
$(1,11,12)$. Different kinetics of these reactions are probably caused by varying numbers of the open-chain forms of sugars used in the incubation mixture.

The aim of the present study is to investigate an influence of different experimental conditions, i.e., two concentrations of D-fructose $(50 \mathrm{mmol} / 1$ and $500 \mathrm{mmol} / \mathrm{l})$, as a rapidly glycating monosaccharide, and three incubation temperatures $\left(4{ }^{\circ} \mathrm{C}, 25{ }^{\circ} \mathrm{C}, 37{ }^{\circ} \mathrm{C}\right)$, on the glycation kinetics of ALT and AST, expressed by the rates of decreasing catalytic activities, in the course of a fifty-six-day incubation in vitro. The most prospective experimental design should serve for future glycation studies with aminotransferases under the influences of drugs.

\section{Material and Methods}

\section{Chemicals}

Alanine aminotransferase, $100 \mathrm{U} / \mathrm{mg}$ protein, and cytosolic aspartate aminotransferase, $470 \mathrm{U} / \mathrm{mg}$ protein, both from the porcine heart, suspended in ammonium sulfate, pH 6.0 (Sigma, St. Louis, MO, USA). D-fructose was obtained from Lachema, Brno, Czech Republic. Sodium azide was purchased from Merck, Darmstadt, Germany. All chemicals used were of analytical grade. 


\section{Preparation and incubation of samples}

The suspensions of aminotransferases were centrifuged at $1000 \mathrm{x}$ g at $4{ }^{\circ} \mathrm{C}$ for $20 \mathrm{~min}$. The supernatant was removed and the enzyme pellet dissolved in $6.75 \mathrm{ml} 0.05$ mol/1 sodium phosphate buffer $(\mathrm{pH} 7.4)$ with $0.1 \%$ sodium azide. Following this, the enzyme solutions were used for the preparation of three types of incubation samples; i) with D-fructose in a final concentration of $50 \mathrm{mmol} / \mathrm{l}$, ii) with D-fructose in a final concentration of $500 \mathrm{mmol} / \mathrm{l}$, iii) with the buffer only (control samples). The final enzyme (protein) concentrations were $0.41 \mathrm{mg} / \mathrm{ml}$ (ALT) and $0.34 \mathrm{mg} / \mathrm{ml}$ (AST), and the total volume of samples was 1.5 $\mathrm{ml}$. The samples were incubated for up to 56 days at temperatures of $4{ }^{\circ} \mathrm{C}, 25^{\circ} \mathrm{C}$ or $37^{\circ} \mathrm{C}$.

\section{Determination of aminotransferase activity}

Sample aliquots $(100 \mu \mathrm{l})$ were removed at time zero and on days $4,10,22,35$, and 56 of incubation. After collection, the aliquots were diluted 1:19 (ALT) or 1:90 (AST) with $0.05 \mathrm{~mol} / 1$ phosphate buffer, $\mathrm{pH} 7.4$, in order to obtain catalytic activities within the analytical range of the employed method. The enzyme activities were assayed on a Hitachi 917 analyzer using the common kinetic UV-method with addition of pyridoxal-5'-phosphate to the incubation mixture (Roche Diagnostics, Mannheim, Germany). All experiments were performed in triplicates. ALT and AST catalytic activities were standardized by their measurement in Precinorm U and Precipath U (both from Roche Diagnostics) before and after each assay. The between-run coefficients of variation of the both assays for Precinorm $U$ and Precipath $\mathrm{U}$ were lower than $2.0 \%$.

\section{Statistical analysis}

Absolute values of enzyme activities, taking into account diluting factors, are given as the mean \pm standard deviation (SD).

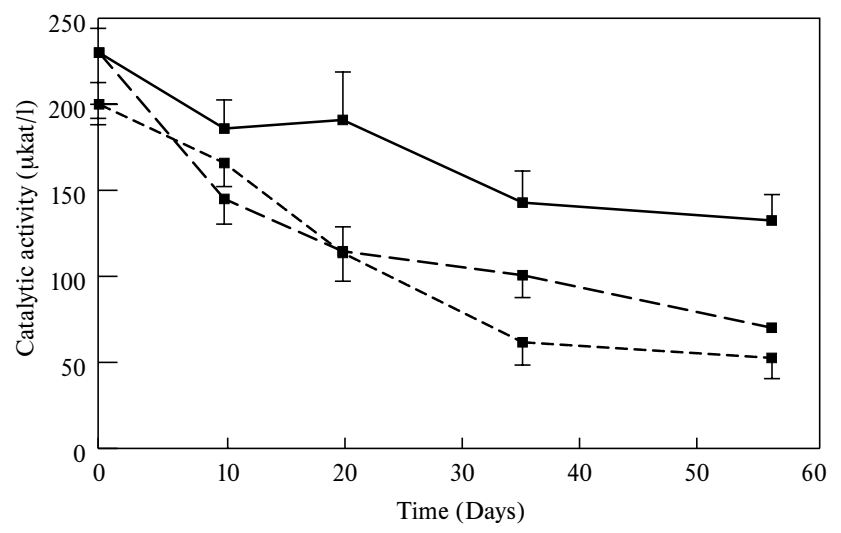

Fig. 1: Stability of ALT during incubation in vitro in control samples (without sugar). ALT was incubated in 0.05 mol/1 phosphate buffer, pH 7.4, at $4{ }^{\circ} \mathrm{C}(\longrightarrow), 25^{\circ} \mathrm{C}$ $(-----)$, and $37^{\circ} \mathrm{C}(-\cdot-\cdot-)$. Results are expressed as the mean value and SD from three independent collections.

\section{Results}

Fig. 1 and Fig. 2 show a long-time fluctuation in catalytic activities of enzymes in control samples (without D-fructose) during a fifty-six-day incubation in $0.05 \mathrm{~mol} / 1$ phosphate buffer, $\mathrm{pH}$ 7.4. The mean initial catalytic activity of ALT in different experiments ranged between 200-225 $\mu \mathrm{kat} / \mathrm{l}$. The decrease, according to the incubation temperature used, was: by $41 \%$ at $4{ }^{\circ} \mathrm{C}$, by $70 \%$ at $25{ }^{\circ} \mathrm{C}$, and by $75 \%$ at $37{ }^{\circ} \mathrm{C}$ on day 56 . On the other hand, almost unchanged AST activity was observed in the course of incubation time at all examined temperatures. In comparison with ALT, inhibition of the initial AST activity $\left(793 \pm 16 \mu \mathrm{kat} / 1\right.$ at $4{ }^{\circ} \mathrm{C}$; $983 \pm 96 \mu \mathrm{kat} / 1$ at $25^{\circ} \mathrm{C} ; 839 \pm 22 \mu \mathrm{kat} / 1$ at $37{ }^{\circ} \mathrm{C}$ ) in the control samples was lower than $20 \%$ by day 56 .

Fig. 3 presents enzyme inhibition reached at three examined temperatures in the presence of either $50 \mathrm{mmol} / 1$ or $500 \mathrm{mmol} / 1 \mathrm{D}$-fructose. Residual catalytic activities in these figures are exhibited in the percentage of the appropriate control. In the case of ALT (Fig. 3A), no catalytic activity was found after 35 days at $25^{\circ} \mathrm{C}$ and after 20 days at $37^{\circ} \mathrm{C}$ of incubation with $50 \mathrm{mmol} / \mathrm{l} \mathrm{D}$-fructose. A fifty-six-day incubation at $25{ }^{\circ} \mathrm{C}$ led to a partial inhibition of AST (to $40 \%$ of the initial activity). At $37^{\circ} \mathrm{C}$, AST almost completely lost its enzymatic activity (Fig. 3B). As demonstrated, D-fructose in a concentration of $50 \mathrm{mmol} / 1$ did not inhibit catalytic activity of either enzyme at $4{ }^{\circ} \mathrm{C}$.

In Fig. 3C and Fig. 3D, decreasing enzyme activities in the samples incubated in the presence of $500 \mathrm{mmol} / 1$ D-fructose for 56 days are described. At $37{ }^{\circ} \mathrm{C}$ and at the above-mentioned D-fructose concentration, ALT inhibition was as rapid as at a concentration of $50 \mathrm{mmol} / \mathrm{l}$. At $25^{\circ} \mathrm{C}$, the course of decrease in ALT activity at $500 \mathrm{mmol} / 1$ D-fructose was faster than at the lower D-fructose concentration (Fig. 3C). Complete AST inhibition on day 35 at $25^{\circ} \mathrm{C}$ and on day 20 at $37^{\circ} \mathrm{C}$ witnesses to a more rapid AST gly-

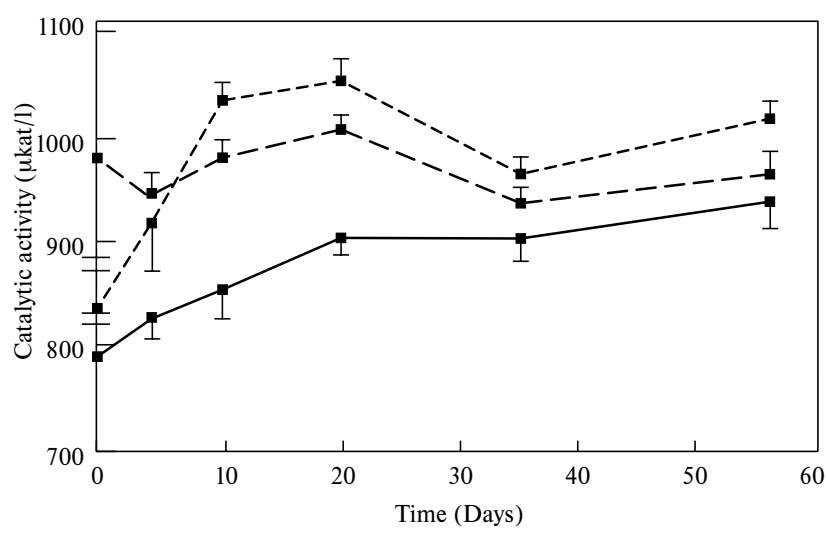

Fig. 2: Stability of AST during incubation in vitro in control samples. AST was incubated in $0.05 \mathrm{~mol} / 1$ phosphate buffer, $\mathrm{pH}$ 7.4. at $4{ }^{\circ} \mathrm{C}(-), 25^{\circ} \mathrm{C}(------)$, and $37^{\circ} \mathrm{C}$ $(-\cdot-\cdot-)$. Results are expressed as the mean value and SD from three independent collections. 

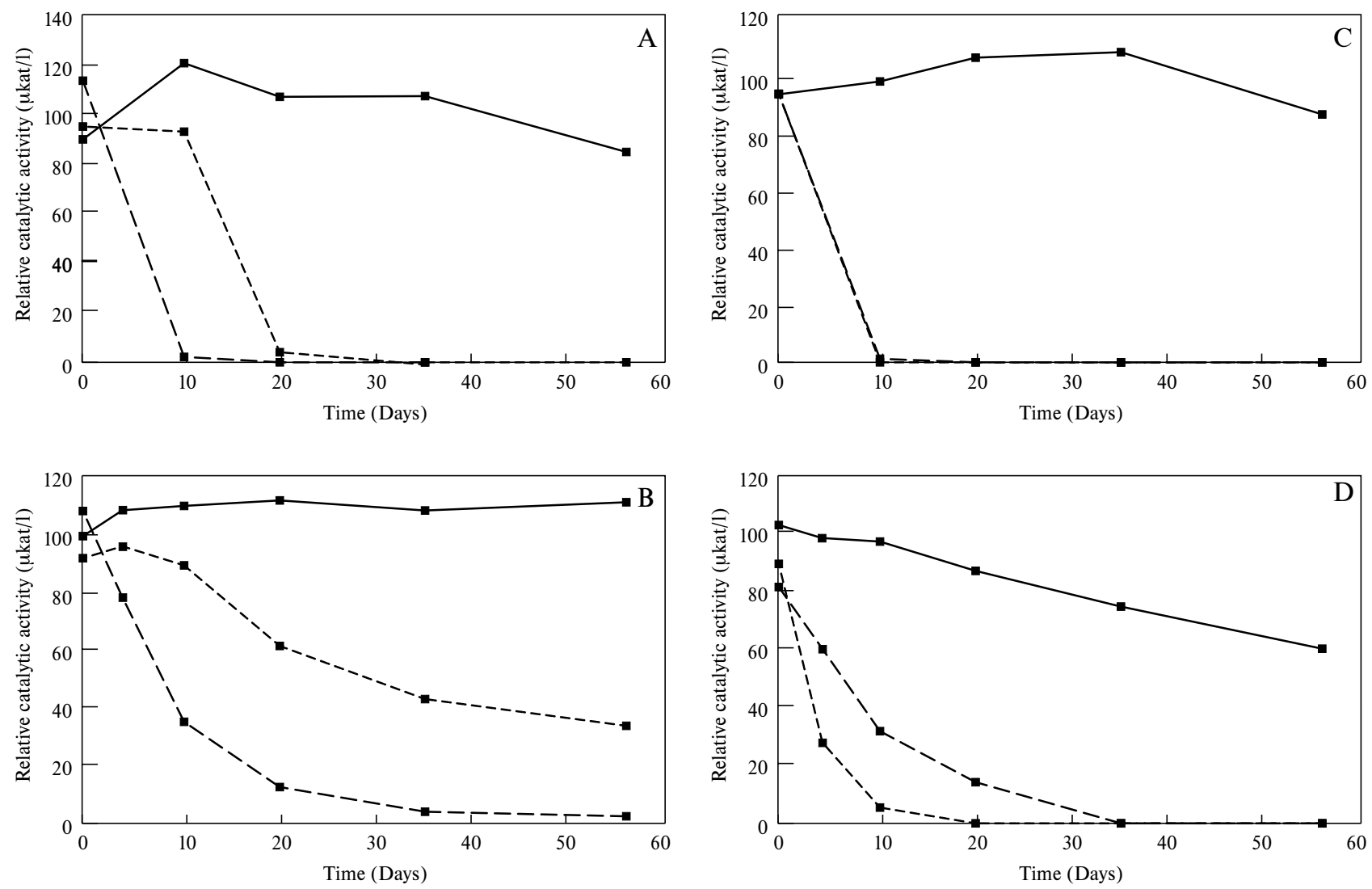

Fig. 3: Inhibitory effect of glycation on the catalytic activity of enzymes incubated in $0.05 \mathrm{~mol} / 1$ phosphate buffer, $\mathrm{pH} 7.4$ at $4{ }^{\circ} \mathrm{C}(-), 25^{\circ} \mathrm{C}(-----)$ and $37{ }^{\circ} \mathrm{C}(----)$ for up to 56 days: (A): ALT incubated with $50 \mathrm{mmol} / 1 \mathrm{D}$-fructose; (B): AST with $50 \mathrm{mmol} / 1 \mathrm{D}$-fructose; (C): ALT with $500 \mathrm{mmol} / 1 \mathrm{D}$-fructose; (D): AST with $500 \mathrm{mmol} / 1 \mathrm{D}$-fructose. The values show residual catalytic activities of the enzymes related to the appropriate control.

cation by $500 \mathrm{mmol} / \mathrm{l} \mathrm{D}$-fructose in comparison with 50 mmol/1 D-fructose (Fig. 3D). In contrast, $4{ }^{\circ} \mathrm{C}$ incubation of ALT and AST in the presence of $500 \mathrm{mmol} / 1$ fructose did not lead to total enzyme inhibition even after 56 days.

\section{Discussion}

In the body, protein glycation leads to a structural modification of various tissue, cell, or plasma proteins, which can change not only their conformation but in many cases also impair their physiological functions $(2,5,6,7,9,13)$. Amadori product, the first stable glycation product, slowly undergoes rearrangement, dehydration, oxidative fragmentation, and cross-linking reactions leading to advanced glycation end products (AGEs), especially in long-lived proteins. Thus cataract, retinopathy, macroangiopathy, nephropathy, and neuropathy can be caused (3).

In the present paper we examined the influence of D-fructose on the rate of protein glycation at various experimental conditions. As the substrate of glycation, purified aminotransferases from the porcine heart, the molecules that are relatively resistant towards thermal denaturation in conditions in vitro, were used. This property of aminotransferases made it possible to observe their changes from early steps to the stage of irreversible protein changes associated with the loss of their catalytic activity.

In the controls (no fructose added), the study demonstrated a high stability of AST during fifty-six-days of incubation in $0.05 \mathrm{~mol} / 1$ phosphate buffer, $\mathrm{pH} 7.4$. We received a similar course of the inhibition curve as Okada et al. (11), who previously published a short-time study (120 hours only).

In our former study, the results suggested that D-fructose might be a suitable model sugar for glycation experiments with aminotransferases (1). The present paper confirms this finding and demonstrates the dependence of D-fructose glycation on the defined experimental temperature. The finding on the enzyme stability or changes during the incubation at the employed temperatures and under the influence of fructose seems to be pre-analytically important for either storing or room-temperature manipulation with serum specimens, in which a high concentration of fructo- 
se is clinically expected (essential fructosuria, a human genetic defect of hepatic fructokinase).

In the case of ALT, there was no difference in the decrease of enzyme activity between the samples with a high concentration $(50 \mathrm{mmol} / \mathrm{l})$ and an extremely high concentration $(500 \mathrm{mmol} / \mathrm{l})$ of D-fructose at $37{ }^{\circ} \mathrm{C}$. In AST, $500 \mathrm{mmol} / 1 \mathrm{D}$-fructose had a more pronounced decreasing effect on the catalytic activity of the enzyme than $50 \mathrm{mmol} / \mathrm{l}$ Unfortunately, the decrease in catalytic activities of both aminotransferases below $20 \%$ of their initial values within a 14-day incubation period did not allow any further study of influences on the enzymes in longer intervals at $37{ }^{\circ} \mathrm{C}$.

Thus, taking into account the highest possible stability of aminotransferase, we suppose that a three-week observation of their residual catalytic activity in the presence of 50 mmol/1 D-fructose at a temperature of $25{ }^{\circ} \mathrm{C}$ seems to be the most prospective experimental design for future glycation studies with ALT and AST.

In conclusion, we tried to define the experimental conditions for effective in vitro studying of protein glycation based on an evident partial or complete loss of the catalytic activity of aminotransferases. We believe that this approach could be a helpful tool not only for a better understanding of early glycation reactions but also for a further research of glycation under the influences of drugs.

\section{Acknowledgement}

This work was supported by the grant GAUK 95/2000 from the Grant Agency of Charles University in Prague, and by the research projects LN00B125 and MSM 111600002 of the Czech Ministry of Education. We wish to express our thanks to Ms. Irena Žáková and Ms. Markéta Steidlová, former students of the Faculty of Pharmacy in Hradec Králové, for their technical assistance in glycation experiments.

\section{References}

1. Beránek M, Dršata J, Palička V. Inhibitory effect of glycation on catalytic activity of alanine aminotransferase. Mol Cell Biochem 2001;218:35-9.

2. Brownlee M, Vlassara H, Cerami A. Nonenzymatic glycosylation reduces the susceptibility of fibrin to degradation by plasmin. Diabetes 1983;32:680-4

3. Brownlee M. Glycation and diabetic complications. Diabetes 1994:43:836-41.

4. Dolhofer R, Siess EA, Wieland OH. Inactivation of bovine kidney -N-acetyl-D-glucosaminidase by nonenzymatic glucosylation. Hoppe-Seylers Z Physiol Chem 1982;363:1427-36

5. Dolhofer R, Siess EA, Wieland OH. Nonenzymatic glycation of immunoglobulins leads to an impairment of immunoreactivity. Biol Chem Hoppe-Seyler 1985;366:361-6

6. Fu MX, Wells-Knecht KJ, Blackledge JA, Lyons TJ, Thorpe SR, Baynes J. Glycation, glycoxidation, and cross-linking of collagen by glucose. Diabetes 1994;43:676-83.

7. Hitz JB, Dain JA. Glycation of myelin basic protein. Biochem Arch 1988;4: 159-68.

8. Ishiguro M, Takio K, Suzuki M, Oyama R, Matsuzawa T, Titani K. Complete amino acid sequence of human liver cytosolic alanine aminotransferase (GPT) determined by a combination of conventional and mass spectral methods. Biochemistry 1991;30:10451-7.

9. McMillan DE, Brooks SM. Erythrocyte spectrin glucosylation in diabetes. Diabetes 1982;31:64-9.

10. Okada M, Murakami Y, Miyamoto E. Glycation and inactivation of aspartate aminotransferase in diabetic rat tissues. J Nutr Sci Vitaminol 1997;43:463-9.

11. Okada M, Sogo A, Ohnishi N. Glycation reaction of aspartate aminotransferase by various carbohydrates in an in vitro system. J Nutr Biochem 1994;5:485-9.

12. Okada M, Harima H, Hosoi Y, Sogo A. Influences of some low molecular compounds on enzymatic activity and isoelectric point of aspartate aminotransferase from rat liver. J Nutr Sci Vitaminol 1993;39:311-21.

13. Yudkin JS, Cooper MB, Gould BJ, Oughton J. Glycosylation and cross-linkage of cardiac myosin in diabetic subjects: a post-mortem study. Diabet Med $1988 ; 5: 338-42$

Submitted March 2002.

Accepted May 2002.

Prof. MUDr. Jaroslav Dršata, CSc., Charles University in Prague, Faculty of Pharmacy in Hradec Králové, Department of Biochemical Sciences, Heyrovského 1203, 50005 Hradec Králové, Czech Republic. e-mail:drsata@faf.cuni.cz 